\title{
Cinema and literary education from a gender perspective
}

\author{
María-José Molina-García ${ }^{1}$, Ana-Alicia Marmolejo Portales² \\ ${ }^{1}$ University of Granada
}

\begin{abstract}
This research, which is framed in an $\mathrm{R}+\mathrm{D}$ project on Literary Education, aims to explore and validate strategies to bring to achieve educational competencies in Primary Education students. Specifically, this study focuses on the design of the didactic program. The methodology adopts a bimodal approach based the cinema as an educational resource and on the filmic text as a textual typology in the area of Language Teaching to develop the communicative competence of the students in all its aspects: pragmatic, linguistic, sociolinguistic and literary (Santana, Molina-García and Enrique, 2020). At the same time, content on equality is used in a transversal way, using Disney films and the evolution of the female role in them because cinema is a dynamic factor to help promote human values (Pallarés Ambrós and Breu, 2011). The experimental subjects are students between 10 and 11 years old. The project objective is motivating this students towards the analysis of texts that improve their critical thinking and contribute to their Values Education through Literary Education.
\end{abstract}

Keywords: actives methodologies; educational cinema; literary education; Primary Education. 


\section{$3^{\text {rd }}$ International Conference on Research in TEACHING and EDUCATION}

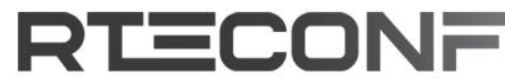

15 - 17 December, 2020

Berlin, Germany

\section{Introduction}

Working with cinema in the Primary classroom can be a motivating adventure for student learning. Watching a movie and living its magic make the student develop imagination and creativity. It is important that teachers use new technologies, a different methodology than the use of the book, more attractive and currently well known by students. Therefore, the cinema can be an ally of learning in the classroom and through it, you can work on topics, content, and skills that are part of the curriculum.

According to Pallarés Ambrós and Breu (2011, p.8) "the use of cinema in the classroom is a key dynamic factor to help promote human values in a transversal and interdisciplinary way and to thus contribute to developing values and elements of personal identity and belonging". For this reason, a good use of cinema as a resource in the classroom should be put into practice in a transversal way, using it as a tool to work on contents that appear or not, in any subject, in addition to topics related to values, emotions, feelings, etc. environment, peace, equality.

The communication channel used in the cinema is audiovisual. However, it should not be forgotten that cinema first passes through a written channel (the book and the script). That is, in the case of recreation, one starts from a genre of written transmission (the literary work), to a written one to be said (the script) to arrive at a genre of oral transmission (the film) and the three are related with the poetic function of language. As the CEFR indicates, its users can take into account and determine "what recreational and aesthetic uses of the language the student will have to learn, how they will be trained to do so or what will be required of them in this regard" (MCER, 2001:60). An interesting textual typology is thus configured with specific pragmatic, linguistic, sociolinguistic and literary characteristics that are susceptible to analysis and, therefore, to be worked on in the classroom (Santana, Molina-García and Enrique, 2020).

Some of the stories that are told in Disney movies and some of the princesses that appear, come from literary stories, which do not usually have a happy ending. It was Roy Disney who proposed to his brother Walt, to bring to the screen these stories by classic authors, such as Hans Christian Andersen and The Brothers Grimm. But the Disney knew that they had to adapt these stories to the children's audience and to do so they would change the endings and eliminate the hardest parts of the story. In this way, they would ensure success.

However, in the Disney factory the role of women has varied. Snow White (1937), Cinderella (1950) and Aurora (1959), are the classic fairy tale women, who need to be saved from death by a prince charming with the classic true love kiss that will wake them up. Years later, this role changes. A new Disney princess emerges: Ariel, from Beauty and the Beast (1991). She is an educated princess, who wants to train and that is why she dedicates herself to reading, ignoring others. She is also adventurous and breaks with her father's rules. Jasmine (1992), Pocahontas (1995), Esmeralda (1996) or Mulán (1998) are women with character, determined and brave who fight for their people or for ideals, far from the feminine role of the first Disney women. With the latest Disney princesses, Elsa and Anna from Frozen (), the focus of attention is not the search for a marriage but the internal struggle to overcome fears, anxieties and worries.

Therefore, in the present work, it is intended to use the cinema as a didactic resource, worked in two different ways: On the one hand, to promote the critical spirit of the child, 


\section{$3^{\text {rd }}$ International Conference on Research in TEACHING and EDUCATION}

RZCONF

15 - 17 December, 2020

Berlin, Germany

analyzing the characters, the values they transmit and the teachings that the film want to transmit. On the other hand, from the contents of the language area prescribed by the educational system, among which will be the cohesion of the text, links, verb tenses and adjectives, punctuation marks, the filmic narrative and norms and structures for the production of different oral and written texts. The area of language in Primary Education aims to develop basic skills in the use of language, such as listening, speaking, reading and writing. The acquisition of these communication skills can only be achieved by reading different kinds of texts, their understanding and reflection on them, aspects that will be present in this proposal.

\section{Methods}

In the work presented, a Project Based Learning (PBL) methodology is followed. to enhance, through the activities designed group work but also the autonomy of students when making decisions, investigating, carrying out collaborative work and cooperative learning, learning by themselves and applying what they have learned to new situations. Following the principles of active, meaningful, motivating, cooperative learning and the use of ICT.

The role of the teacher is to promote the involvement and autonomy of the students in individual work and in teamwork and collaboration. In the same way, it must stimulate critical thinking and reflection in students, encouraging them to discover and research in order to provoke in the student an increase in their entrepreneurial spirit and personal initiative.

\subsection{Sample}

A non-probabilistic convenience sampling method has been used, selecting a Compulsory Primary Education classroom of fifth-year students, which is composed of sixteen boys and fourteen girls aged 10-11, five of them of berber culture, one of jewish culture and the rest of European origin. One of these students is diagnosed with TDA-H or attention deficit.

All of them study in a School in Melilla, a Spanish city located in North Africa, which consists of approximately 85000 people according to the last published census (INE, 2019). Five different cultural communities coexist in this city: people of European, Berber, Jewish, Gypsy and Hindu origin. The first three groups constitute most of the population. The special location of the city between Africa and Europe and the constant immigration flows has a decisive socio-cultural and economic influence; the immediate impact on education is the formation of culturally diverse classrooms.

According to the Education Center Project (ECP) for the 2019/2020 school year, the students belong to the upper-middle class with parents who have achieved a certain educational level, including university studies. Data indicate that school failure decreases in this context and that these students have reference books at their disposal; the majority have an adequate place to study at home and a library in some cases. However, these students do not have interest in the reading habit.

\subsection{Instrument}




\section{$3^{\text {rd }}$ International Conference on Research in TEACHING and EDUCATION}

RZECONF

15 - 17 December, 2020

Berlin, Germany

The instrument designed as a dependent variable is a didactic proposal for intervention within the framework of the Organic Law 8/2013 for the Improvement of Educational Quality (abridge in Spanish as LOMCE). This law currently governs Education in Spain, together with the Royal Decree-Laws (RD) and Orders of the Ministry of Education, Culture and Sports (MECS) oriented to the educational stage of Compulsory Secondary Education, always framed within the LOMCE.

For this educational stage, the legal regulations prescribe the design of programs based on competencies, seeking to achieve key competencies. In the program elaborated in this research, it is possible to contribute to the development of the following competences: Language Communication Competence (LCC), Digital Competence (DC), Learning to Learn Competence (LLC) and Social and Civic Competence (SCC).

Spanish law also sets general objectives in the area of Language and Literature for the end of the educational stage that are collected in the following table:

Table 1: General objectives of the area of Spanish Language and Literature

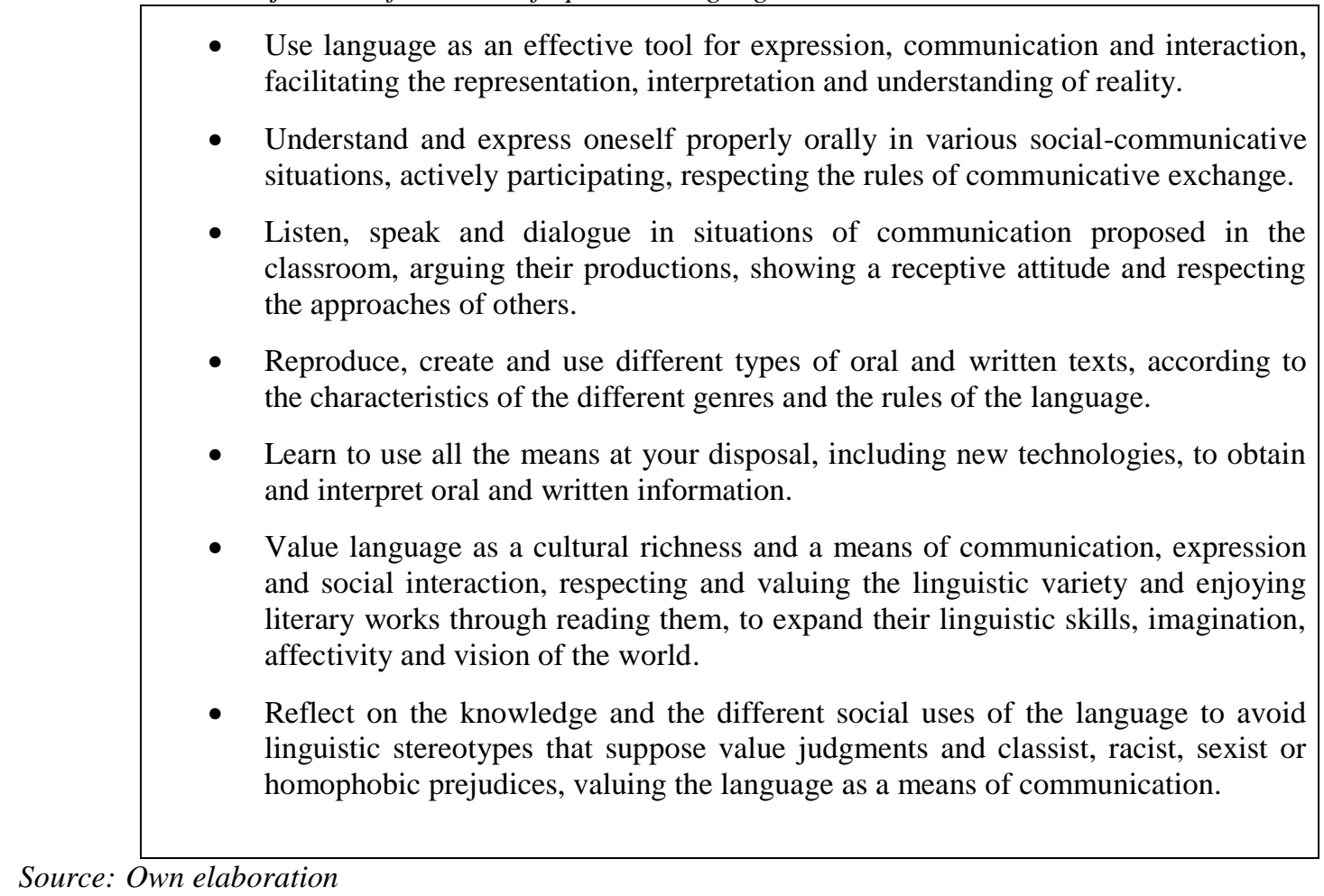

The current legal framework establishes the general contents classified by blocks and can be specified in the didactic proposals. These blocks are: Oral communication: speaking and listening; Written communication: read; Written communication: writing and Knowledge of the language. At the same time, the current law also recommends including cross-cutting themes, such as equality between men and women and the prevention of gender violence. 


\section{$3^{\text {rd }}$ International Conference on Research in TEACHING and EDUCATION}

RZECONF

15 - 17 December, 2020

Berlin, Germany

The students' evaluation criteria and learning standards (also included in the legal framework) can be related to the proposed program topic. Therefore, these evaluation criteria and learning standards can be classified according to their content.

\subsection{Process}

The implementation of active methodologies involves students and makes them enjoy the time they spent in the Language and Literature classroom; The programmed activities are aimed at awakening their motivation so that they develop an interest in reading. From these methodologies and problem-solving tasks, the student finds himself in an educational environment that encourages him to think about his long-term learning.This approach aims to present unpredictable problems that may arise both in school and in life real to students and provide them with the necessary tools to solve these problems on their own. Therefore, it is very important to work with different media and different subjects that complement, through interdisciplinarity, the task of the Language and Literature classroom to achieve comprehensive learning.

Active methodologies, such as problem solving, place the student as the protagonist of the teaching-learning process, so that he can apply the knowledge acquired to the process of training skills and assimilation of the contents. These methodologies are based on important methodological principles, such as student motivation and self-esteem (Fernández-Lasarte, Ramos Díaz, Goñi Palacios and Rodríguez Fernández, 2019), interdisciplinarity (MartínPiñol, Calderón-Garrido and Gustems-Carnicer, 2016), participatory and collaborative learning (Ortega, 2016), education in values and critical thinking (Laiton-Poveda, 2010), among others.

\section{Results}

The result obtained is a didactic proposal, derived from the current educational legal framework, where the specific contents of the area of Didactics of Language and Literature are addressed, distributed in the aforementioned blocks and that are exposed in the following table:

Table 2: List of specific contents of Spanish Language and Literature

\begin{tabular}{|c|c|}
\hline BLOCKS & CONTENUS \\
\hline \multirow{4}{*}{$\begin{array}{l}\text { Block 1: } \\
\text { Oral communication: } \\
\text { speaking and listening }\end{array}$} & $\begin{array}{l}\text { Participation in communicative situations: interviews, } \\
\text { performances, dubbing ... }\end{array}$ \\
\hline & $\begin{array}{l}\text { Oral language as a communication and learning tool through } \\
\text { interviews, exhibitions, film dubbing, cinematographic } \\
\text { performances. }\end{array}$ \\
\hline & Listening, reproduction and dramatization of film texts. \\
\hline & $\begin{array}{l}\text { Comprehension and characteristics of oral messages in film } \\
\text { narrative and dialogues. }\end{array}$ \\
\hline
\end{tabular}




\section{$3^{\text {rd }}$ International Conference on Research in TEACHING and EDUCATION}

RZCONF

15 - 17 December, 2020

Berlin, Germany

\begin{tabular}{|c|c|}
\hline & $\begin{array}{l}\text { Understanding of the messages and oral and gestural } \\
\text { expressions made by Disney characters. }\end{array}$ \\
\hline \multirow{3}{*}{$\begin{array}{l}\text { Block 2: } \\
\text { Written communication: } \\
\text { read }\end{array}$} & $\begin{array}{l}\text { Reading and listening to different } \\
\text { dialogues and / or songs that appear in the Disney movies to } \\
\text { be worked on. }\end{array}$ \\
\hline & Comprehension of narrative texts and dialogues. \\
\hline & $\begin{array}{l}\text { Identification and critical opinion of the messages and values } \\
\text { transmitted by the different Disney characters. }\end{array}$ \\
\hline \multirow{3}{*}{$\begin{array}{l}\text { Block 3: } \\
\text { Written communication: } \\
\text { writing }\end{array}$} & $\begin{array}{l}\text { Production of texts to communicate knowledge, experiences } \\
\text { and needs through narrations, dialogues, interviews, film } \\
\text { scripts, etc. }\end{array}$ \\
\hline & $\begin{array}{l}\text { Use of corresponding links and verb tenses (past, present and } \\
\text { future) used appropriately to maintain the cohesion of the } \\
\text { message. }\end{array}$ \\
\hline & $\begin{array}{l}\text { Use of structures and strategies to construct narrative texts } \\
\text { and dialogues. }\end{array}$ \\
\hline \multirow{4}{*}{$\begin{array}{l}\text { Block 4: } \\
\text { Knowledge of the language. }\end{array}$} & $\begin{array}{l}\text { Use of the rules of accentuation and punctuation marks in the } \\
\text { creation of narrative texts and dialogues. }\end{array}$ \\
\hline & $\begin{array}{l}\text { Recognition of the different verb tenses (past, present, } \\
\text { future). }\end{array}$ \\
\hline & Dramatization of different Disney movies. \\
\hline & $\begin{array}{l}\text { Knowledge of the role of women in traditional stories taken } \\
\text { to the cinema such as: Beauty and the Beast, Snow White, } \\
\text { Frozen, etc. }\end{array}$ \\
\hline
\end{tabular}

The activities designed to achieve the competencies and explain the programmed contents are classified into: initiation activities (aimed at analyzing the knowledge of previous students so that the teacher can adapt their performance thanks to a certain curricular flexibility; motivational activities (designed to motivate to students and connect with their interests, in addition to being closely linked to the Competence to Learn to Learn); and development activities (aimed at consolidating the acquisition of the contents explained in the classroom) proposed competencies). Some examples of all this type of activities are presented in the following table: 


\section{$3^{\text {rd }}$ International Conference on Research in TEACHING and EDUCATION}

RZCONF

15 - 17 December, 2020

Berlin, Germany

Table3: Sample of different types of activities.

\begin{tabular}{|c|l|}
\hline \multirow{4}{*}{ Initiation activities } & $\begin{array}{l}\text { Brainstorm Disney stories and movies that you have seen } \\
\text { about them. }\end{array}$ \\
\cline { 2 - 3 } Motivational activities & $\begin{array}{l}\text { Find information about the Walt Disney bibliography, } \\
\text { created characters... }\end{array}$ \\
\cline { 2 - 3 } Investigate the origin in the popular tales of Disney movies \\
\cline { 2 - 3 } & Imitation of characters to be guessed \\
\hline \multirow{5}{*}{ Development activities } & Interviews with movie characters \\
\cline { 2 - 2 } & Scripting for Made-Up Scenes \\
\cline { 2 - 2 } & $\begin{array}{l}\text { Elaboration of scripts with changes in the characteristics of } \\
\text { the characters }\end{array}$ \\
\cline { 2 - 2 } & Dramatization of movie scenes \\
\cline { 2 - 3 } & Scene dubbing \\
\cline { 2 - 2 } & Imitation of characters to be guessed \\
\cline { 2 - 2 } & Essays on the feelings of the characters \\
\cline { 2 - 2 } & Oral and written speeches \\
\hline Final project & Organization of a Disney Awards gala \\
\hline
\end{tabular}

\section{Conclusion}

The cinema is an essential and ideal educational tool in the Primary Education classroom. Through a different and innovative methodology, the necessary content is worked on to promote the emotional and intellectual development of the student.

The main task of a teacher is to develop creativity, imagination, self-learning in students and make them feel unique and capable of creating something for themselves, regardless of their abilities, age or gender.

Through the proposal presented, both the curricular aspect of the language is worked on, as well as the different values transmitted in Disney films, which bring children closer to a society where they must learn to solve and solve problems on their own.

On the other hand, investigating the evolution of the female role through these films allows the perception of the development of this vital aspect and the creation of favorable attitudes for the awareness of gender equality.

\section{Acknowledgment}

This paper is an output of the science project I+D+I PID2019-105913RB-I00 funded by the Ministry of Economy and Competitiveness.

\section{References}

Fernández Lasarte, O., Ramos Díaz, E., Goñi Palacios, E., and Rodríguez Fernández, A. (2019). Estudio comparativo entre educación superior y educación secundaria: efecto del apoyo social percibido, el autoconcepto y la reparación emocional en el rendimiento académico. Educación $X X 1,22(2)$,

165-185.

doi:http://dx.doi.org/10.5944/educXX1.22526 


\section{$3^{\text {rd }}$ International Conference on Research in TEACHING and EDUCATION}

RTECONF

15 - 17 December, 2020 Berlin, Germany

INE (2019). Censo de Población y Viviendas 2019. Melilla: Instituto Nacional de Estadística.

Laiton-Poveda, I. (2010). Formación de pensamiento crítico en estudiantes de primeros semestres de educación superior. Revista Iberoamericana de Educación, 53(3), 1-7.

Martín-Piñol, C., Calderón-Garrido, D., y Gustems-Carnicer, J. (2016). Interdisciplinariedad y tecnología en la educación artística desde la experiencia creativa. Arte y Políticas de Identidad, 14, 79-95.

Available: https://search.proquest.com/docview/1862887871?accountid=14542

Organic Law 8/2013, de 9 de diciembre, para la Mejora de la Calidad Educativa. (BOE núm. 295, de 10 de diciembre de 2013, 97858-97921).

Ortega, O. (2016). Dinámica de grupos: técnicas de organización de eventos. Ecos Ediciones.

Pallarés Ambrós, A. and Breu, R. (2011). Educar en medios de comunicación. La Educación Mediática. Barcelona:Graó.

Santana, JJ, Molina-García, MJ and Enrique Mirón, C. (2020). Tampopo: un análisis fílmico de carácter gastronómico, Ética y Cine Journal, vol. 10, (2), pp. 83-88. 